\title{
Transfer of dioxin risk between nine major municipal waste incinerators in Taiwan
}

\author{
Hwong-wen Ma ${ }^{\mathrm{a}}$, Yen-Ling Lai ${ }^{\mathrm{b}}$, Chang-Chuan Chan ${ }^{\mathrm{b}, *}$ \\ ${ }^{a}$ Graduate Institute of Environmental Engineering, College of Engineering, National Taiwan University, 71 Chou-Shan Road, Taipei 106, Taiwan \\ ${ }^{\mathrm{b}}$ Institute of Occupational Medicine and Industrial Hygiene, College of Public Health, National Taiwan University, Room 1447, \\ No. 1, 1st, Sec. Jen-ai Road, Taipei, Taiwan
}

Received 12 October 2001; accepted 8 February 2002

\begin{abstract}
The objective of this study was to assess site-specific carcinogenic risks of incinerator-emitted dioxins and risk transfers among the areas covered by nine municipal incinerators in Taiwan. We used actual emission data and the industrial source complex short-term model (ISCST3) to determine the dioxin impact areas within the $8 \times 8-\mathrm{km}$ simulation regions surrounding the incinerators. We then used multimedia model to estimate cancer risks in individual impact areas for two exposure scenarios, which were sufficient (SFP) and insufficient food production (IFP) for residents' consumption in each impact area. We also used information of food supply and consumption between impact areas to calculate risk transfers among these nine incinerators. We found that dioxins' carcinogenic risks ranged from $1.4 \times 10^{-8}($ Incinerator F) to $7.1 \times 10^{-5}$ (Incinerator A) for the nine incinerators under the exposure scenario of SFP, and ranged from $8.7 \times 10^{-8}$ (Incinerator D) to $1.1 \times 10^{-6}$ (Incinerator E) under the exposure scenario of IFP. The food ingestion was the main exposure pathway, which accounted for $64-$ $99 \%$ of total dioxin risks among nine impact areas. For the nine major food items consumed by residents in the impact areas, eggs (14-35\%) and chicken (11-26\%) were two main routes of dioxin exposure in the SFP scenario, while chicken (8-78\%) and vegetables $(0.2-81 \%)$ were two main routes of dioxin exposure in the IFP scenario. Significant risks of dioxins were transferred among incinerators, which accounted for up to $88 \%$ among the incinerators. Incinerator E was the major risk-exporting source to six Incinerators C, D, F, G, H, and I. For these six incinerators, Incinerator E accounted for their 51-88\% imported risks. We concluded that risk transfers among incinerators through routes of food consumption should be considered in assessing health risks associated with incinerator-emitted dioxins in Taiwan. We should place high priority on implementing control measures to lower dioxin emissions in important food-exporting areas like Incinerator E. We should also emphasize analyzing dioxin contents in eggs, chicken, and vegetables in order to improve dioxin-related health risk assessments in the future. (C) 2002 Elsevier Science Ltd. All rights reserved.
\end{abstract}

Keywords: PCDDs; PCDFs; Risk assessment; Risk transfers; Multimedia model

\section{Introduction}

Polychlorinated dibenzo- $p$-dioxins (PCDDs) and polychlorinated dibenzofurans (PCDFs) are among the most toxic chemicals in the environment. Generation and release of PCDDs and PCDFs from anthropogenic activities have raised tremendous concerns due to these chemicals' acute and chronic health effects, such as immune, nervous, endocrine, reproductive, and carcinogenic potential (WHO, 1999). It is well recognized that waste incineration is the predominate source of dioxin release, accounting for $60 \%$

\footnotetext{
* Corresponding author. Tel./fax: +886-2-23222362.

E-mail address: ccchan@ha.mc.ntu.edu.tw (C.-C. Chan).
}

to more than 90\% (USEPA, 1994a; Alcock et al., 1999; Gotoh and Nakamura, 1999; Lauretis, 1999). In Taiwan, incineration is becoming a dominant municipal waste treatment method. Currently, there are nine major incinerators in operation and another 12 under construction in addition to 150 smaller incinerators. It is estimated that more than $90 \%$ of municipal wastes, which are over 9 million metric tons per year in quantity, will be treated by incineration by year 2003. Apparently, health impacts of dioxin emissions from such a high density of incinerators should be carefully evaluated in order to protect public health.

Quantitative risk assessment is a useful tool to provide such estimation because it can link dioxin releases to the health risks of potential receptors in a systematic way. In the past, health risk assessments on incinerators were usually 
performed without considering interactions among multiple incinerators (Levin et al., 1991; USEPA, 1999). Risk transfer among incinerators may be an important risk assessment issue in Taiwan because incinerators' emission deposition areas and residents' exposure routes via food ingestion can be overlapped. In particular, as food ingestion is an important exposure route of dioxin risks (Päpke, 1998), crossincinerator transportation of foods needs to be evaluated. The transportation of agricultural products throughout Taiwan is very common, whereas the proportion of consuming foods produced locally is quite small. As the foods produced near an incinerator are distributed to various locations across the island of Taiwan, residents living around one incinerator will consume foods contaminated by emissions of other incinerators. Therefore, the risks from the emissions of all the incinerators need to be evaluated simultaneously so that the whole picture of risk distribution can be identified.

This research uses site-specific environmental and exposure information that incorporates food supply and agricultural product production and sale system to perform multimedia risk assessment for nine major municipal waste incinerators. The purpose is to evaluate the health risk distribution of dioxin emissions in the incinerator-impacted areas, and to identify risk transfers among nine incinerators through food transportation across these areas.

\section{Materials and methods}

\subsection{Incinerator and emission characterization}

We included nine incinerators for assessment in this study because they have operated for over 2 years and thus had more complete dioxin-emission data. These incinerators' locations and impact areas are shown in Fig. 1. The average emission rates of the 17 dioxin congeners as well as the basic incinerator characteristics are shown in Table 1. The dioxin-emission rates were averaged from multiyear measurements with three to five samples per year for individual incinerators. The emission rates ranged from 9.95E - 11 (Incinerator F) to $5.29 \mathrm{E}-7$ (Incinerator A) in terms of grams TEQ per second. Five older incinerators, which were $\mathrm{A}, \mathrm{B}, \mathrm{E}, \mathrm{H}$, and $\mathrm{I}$, had the larger emission rates with $10^{-8}$ to $10^{-7}$ order of magnitude. The ages of these nine incinerators ranged from 2 to 9 years. The capacities of individual incinerators ranged from 300 to 1800 tons/day, with a total of 13,650 tons/day. Most incinerators used a combination of semidry scrubber, activated carbon ingestion, and bag filter as air-pollution control devices (APCDs).

\subsection{Multimedia and multiple-pathway exposure modeling}

We used the multimedia exposure assessment framework developed in McKone (1991a,b), California EPA (1993), Crawford-Brown (1997, 1999), and USEPA (1999) to

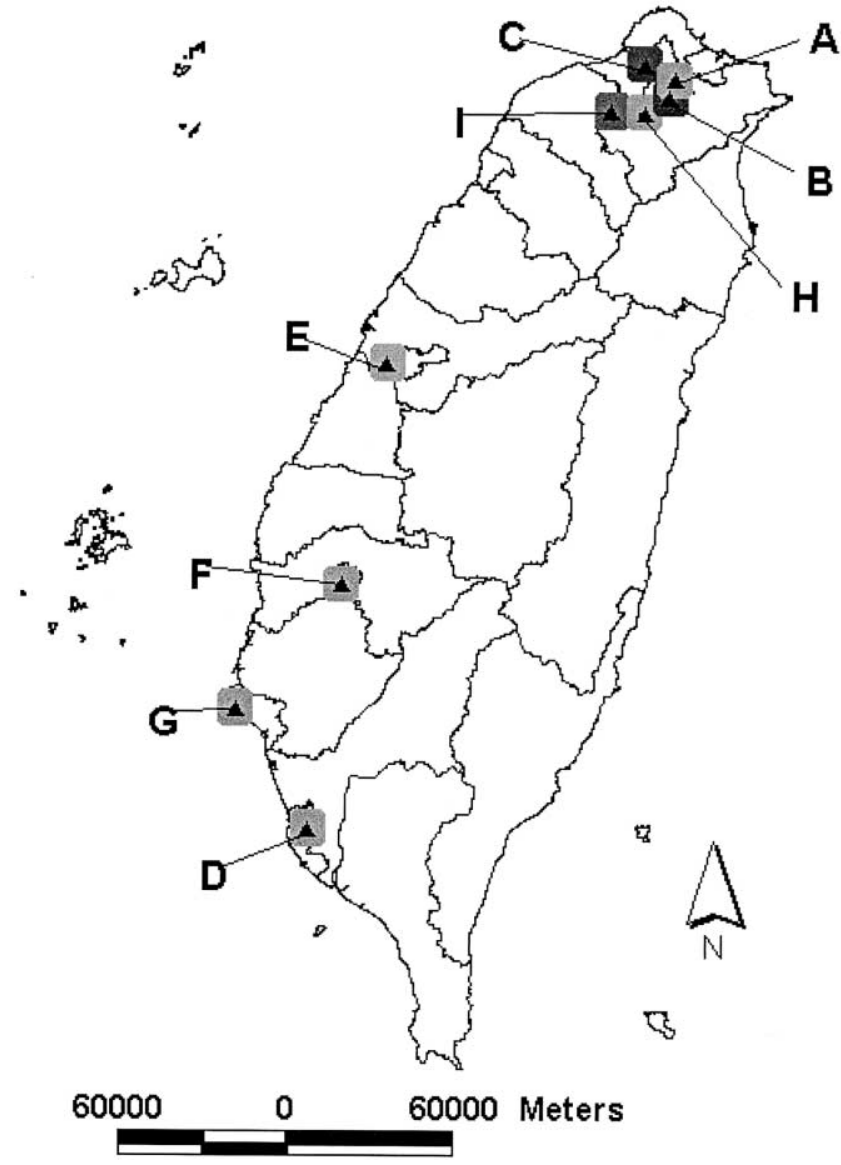

Fig. 1. The spatial distribution of the nine incinerators and associated studied areas in Taiwan.

establish the quantitative relationship linking the dioxins' release from the incinerators to their transport and transfer in the environment, and to their exposures to target populations in the receiving areas. In brief, the multimedia exposureassessment process consists of two connected parts, which are multimedia transport and transformation modeling, and multiple-pathway exposure modeling. In the multimediatransport and transformation-modeling step, we used dioxins' transfer and transformation processes to calculate and predict their temporal and spatial distribution in various environmental media, such as air, soil, and water body. In the multiple-pathway exposure-modeling step, we took model-estimated dioxin concentrations in various environmental media and parameters of various exposure routes, such as inhalation and ingestion, to calculate humans' total exposures to dioxins. The results of exposure-assessment step were the estimated average daily intakes (ADIs) of 17 dioxin congeners.

Our multimedia exposure assessment included the following seven steps. We first defined the areas of $8 \times 8 \mathrm{~km}$ around each of nine incinerators, which were divided into 1600 sectors by a Cartesian grid, as our potential incinerator impact areas. Second, the industrial source complex short-term model (ISCST3) was used to estimate each 
Table 1

Operational parameters and emission rates of 17 dioxin congeners for nine municipal waste incinerators in Taiwan

\begin{tabular}{|c|c|c|c|c|c|c|c|c|c|}
\hline & \multicolumn{9}{|l|}{ Incinerator } \\
\hline & $\mathrm{A}$ & $\mathrm{B}$ & $\mathrm{C}$ & $\mathrm{D}$ & E & $\mathrm{F}$ & G & $\mathrm{H}$ & $\mathrm{I}$ \\
\hline Capacity (tons/day) & 900 & 1500 & 1800 & 900 & 900 & 300 & 900 & 900 & 1350 \\
\hline Stack height (m) & 74 & 125 & 150 & 104 & 120 & 68 & 124 & 117 & 117 \\
\hline Stack diameter (m) & 2 & 2.4 & 2.7 & 1.8 & 1.76 & 1.02 & 1.8 & 2.0 & 2.0 \\
\hline Exit flow (dscm/min) & 1908.83 & 2556.31 & 1921.50 & 1236.33 & 887.48 & 379.84 & 1092.80 & 1597.74 & 1957.61 \\
\hline Exit temperature $\left({ }^{\circ} \mathrm{C}\right)$ & 117.40 & 149.71 & 150.68 & 177.76 & 178.67 & 156.00 & 165.51 & 150.64 & 146.56 \\
\hline Furnace type & $\mathrm{CM}$ & MM & MM & MM & RK & $\mathrm{CM}$ & $\mathrm{CM}$ & RA & RA \\
\hline $\mathrm{APCD}$ & $\mathrm{SD}(\mathrm{AC})+\mathrm{BF}$ & $\mathrm{ESP}(\mathrm{AC})+\mathrm{WS}$ & $\mathrm{SD}(\mathrm{AC})+\mathrm{BF}$ & $\mathrm{SD}(\mathrm{AC})+\mathrm{BF}$ & $\mathrm{SD}+\mathrm{BF}$ & $\mathrm{SD}(\mathrm{AC})+\mathrm{BF}$ & $\mathrm{SD}+\mathrm{BF}$ & $\mathrm{DS}(\mathrm{AC})+\mathrm{BF}$ & $\begin{array}{l}\mathrm{CY}+\mathrm{DS}(\mathrm{AC}) \\
+\mathrm{BF}\end{array}$ \\
\hline \multicolumn{10}{|l|}{ Emission rate $(\mathrm{g} / \mathrm{s})$} \\
\hline $2,3,7,8-\mathrm{TeCDF}$ & $3.39 \mathrm{E}-07$ & $3.23 \mathrm{E}-07$ & $2.14 \mathrm{E}-10$ & $7.88 \mathrm{E}-11$ & $7.71 \mathrm{E}-08$ & $2.61 \mathrm{E}-11$ & $1.34 \mathrm{E}-10$ & $4.47 \mathrm{E}-08$ & $1.86 \mathrm{E}-07$ \\
\hline $1,2,3,7,8-\mathrm{PeCDF}$ & $1.53 \mathrm{E}-07$ & $1.37 \mathrm{E}-07$ & $4.75 \mathrm{E}-10$ & $9.85 \mathrm{E}-11$ & $2.88 \mathrm{E}-08$ & $3.53 \mathrm{E}-11$ & $2.14 \mathrm{E}-10$ & $1.61 \mathrm{E}-08$ & $9.91 \mathrm{E}-08$ \\
\hline $2,3,4,7,8-\mathrm{PeCDF}$ & $2.81 \mathrm{E}-07$ & $2.81 \mathrm{E}-07$ & $6.95 \mathrm{E}-10$ & $2.03 \mathrm{E}-10$ & $5.16 \mathrm{E}-08$ & $3.82 \mathrm{E}-11$ & $7.93 \mathrm{E}-10$ & $2.15 \mathrm{E}-08$ & $9.94 \mathrm{E}-08$ \\
\hline $1,2,3,4,7,8-\mathrm{HxCDF}$ & $7.80 \mathrm{E}-07$ & $5.20 \mathrm{E}-07$ & $1.23 \mathrm{E}-09$ & $3.14 \mathrm{E}-10$ & $7.37 \mathrm{E}-08$ & $4.83 \mathrm{E}-11$ & $1.88 \mathrm{E}-09$ & $3.38 \mathrm{E}-08$ & $1.44 \mathrm{E}-07$ \\
\hline $1,2,3,6,7,8-\mathrm{HxCDF}$ & $3.79 \mathrm{E}-07$ & $2.81 \mathrm{E}-07$ & $1.18 \mathrm{E}-09$ & $2.93 \mathrm{E}-10$ & $4.30 \mathrm{E}-08$ & $3.38 \mathrm{E}-11$ & $8.10 \mathrm{E}-10$ & $1.91 \mathrm{E}-08$ & $8.22 \mathrm{E}-08$ \\
\hline $2,3,4,6,7,8-\mathrm{HxCDF}$ & $1.06 \mathrm{E}-06$ & $6.87 \mathrm{E}-07$ & $1.34 \mathrm{E}-09$ & $5.16 \mathrm{E}-10$ & $5.32 \mathrm{E}-08$ & $4.88 \mathrm{E}-11$ & $1.42 \mathrm{E}-09$ & $2.02 \mathrm{E}-08$ & $8.54 \mathrm{E}-08$ \\
\hline $1,2,3,7,8,9-\mathrm{HxCDF}$ & $9.78 \mathrm{E}-08$ & $4.60 \mathrm{E}-08$ & $1.88 \mathrm{E}-10$ & $4.65 \mathrm{E}-11$ & $6.83 E-09$ & $2.19 \mathrm{E}-11$ & $5.16 \mathrm{E}-11$ & $1.47 \mathrm{E}-09$ & $1.28 \mathrm{E}-08$ \\
\hline $1,2,3,4,6,7,8-\mathrm{HpCDF}$ & $2.31 \mathrm{E}-06$ & $1.35 \mathrm{E}-06$ & $4.76 \mathrm{E}-09$ & $1.38 \mathrm{E}-09$ & $9.52 \mathrm{E}-08$ & $9.57 \mathrm{E}-11$ & $3.47 \mathrm{E}-09$ & $6.82 \mathrm{E}-08$ & $1.92 \mathrm{E}-07$ \\
\hline $1,2,3,4,7,8,9-\mathrm{HpCDF}$ & $6.35 \mathrm{E}-07$ & $3.61 \mathrm{E}-07$ & $1.37 \mathrm{E}-09$ & $5.67 \mathrm{E}-10$ & $2.20 \mathrm{E}-08$ & $2.84 \mathrm{E}-11$ & $2.92 \mathrm{E}-10$ & $1.17 \mathrm{E}-08$ & $3.48 \mathrm{E}-08$ \\
\hline OCDF & $3.57 \mathrm{E}-06$ & $1.55 \mathrm{E}-06$ & $4.88 \mathrm{E}-09$ & $3.78 \mathrm{E}-10$ & $0.00 \mathrm{E}+00$ & $6.59 \mathrm{E}-11$ & $1.93 \mathrm{E}-09$ & $1.77 \mathrm{E}-08$ & $1.47 \mathrm{E}-07$ \\
\hline $2,3,7,8-\mathrm{TeCDD}$ & $1.38 \mathrm{E}-08$ & $1.28 \mathrm{E}-08$ & $3.97 \mathrm{E}-11$ & $2.33 \mathrm{E}-11$ & $2.44 \mathrm{E}-09$ & $1.18 \mathrm{E}-11$ & $2.21 \mathrm{E}-11$ & $1.61 \mathrm{E}-09$ & $6.60 \mathrm{E}-09$ \\
\hline $1,2,3,7,8-\mathrm{PeCDD}$ & $3.91 \mathrm{E}-08$ & $4.39 \mathrm{E}-08$ & $2.81 \mathrm{E}-10$ & $8.65 \mathrm{E}-11$ & $6.83 E-09$ & $2.53 \mathrm{E}-11$ & $2.04 \mathrm{E}-10$ & $3.65 \mathrm{E}-09$ & $1.68 \mathrm{E}-08$ \\
\hline $1,2,3,4,7,8-\mathrm{HxCDD}$ & $4.76 \mathrm{E}-08$ & $3.99 \mathrm{E}-08$ & $5.53 \mathrm{E}-10$ & $1.46 \mathrm{E}-10$ & $1.00 \mathrm{E}-08$ & $3.42 \mathrm{E}-11$ & $1.06 \mathrm{E}-10$ & $2.87 \mathrm{E}-09$ & $9.76 \mathrm{E}-09$ \\
\hline $1,2,3,6,7,8-\mathrm{HxCDD}$ & $8.99 \mathrm{E}-08$ & $7.20 \mathrm{E}-08$ & $2.24 \mathrm{E}-09$ & $7.89 \mathrm{E}-10$ & $2.42 \mathrm{E}-08$ & $6.34 \mathrm{E}-11$ & $1.33 \mathrm{E}-09$ & $4.31 \mathrm{E}-09$ & $1.31 \mathrm{E}-08$ \\
\hline $1,2,3,7,8,9-\mathrm{HxCDD}$ & $9.78 \mathrm{E}-08$ & $7.60 \mathrm{E}-08$ & $1.49 \mathrm{E}-09$ & $4.38 \mathrm{E}-10$ & $2.29 \mathrm{E}-08$ & $4.22 \mathrm{E}-11$ & $7.90 \mathrm{E}-10$ & $5.12 \mathrm{E}-09$ & $1.91 \mathrm{E}-08$ \\
\hline $1,2,3,4,6,7,8-\mathrm{HpCDD}$ & $8.86 \mathrm{E}-07$ & $6.26 \mathrm{E}-07$ & $1.50 \mathrm{E}-08$ & $9.06 \mathrm{E}-09$ & $1.29 \mathrm{E}-07$ & $8.29 \mathrm{E}-10$ & $1.09 \mathrm{E}-08$ & $2.40 \mathrm{E}-08$ & $7.57 \mathrm{E}-08$ \\
\hline OCDD & $2.78 \mathrm{E}-06$ & $1.68 \mathrm{E}-06$ & $1.67 \mathrm{E}-08$ & $1.05 \mathrm{E}-08$ & $1.22 \mathrm{E}-07$ & $1.06 \mathrm{E}-09$ & $1.84 \mathrm{E}-08$ & $2.07 \mathrm{E}-08$ & $1.54 \mathrm{E}-07$ \\
\hline g TEQ/s & $5.29 \mathrm{E}-07$ & $4.32 \mathrm{E}-07$ & $1.75 \mathrm{E}-09$ & $5.90 \mathrm{E}-10$ & $7.01 \mathrm{E}-08$ & $9.95 \mathrm{E}-11$ & $1.43 \mathrm{E}-09$ & $3.10 \mathrm{E}-08$ & $1.36 \mathrm{E}-07$ \\
\hline $\begin{array}{l}\text { Emission concentration } \\
\qquad\left(\mathrm{ng} \mathrm{TEQ} / \mathrm{m}^{3}\right)\end{array}$ & 6.67 & 4.68 & 0.06 & 0.03 & 4.79 & 0.02 & 0.11 & 1.20 & 3.80 \\
\hline
\end{tabular}

CM: continuous mechanical; MM: mass-burn mechanical; RK: rotary kiln; RA: reverse acting. SD: semidry scrubber; AC: activated carbon injection; BF: bag filter; CY: cyclone; DS: dry scrubber; ESP: electrostatic precipitator; WS: wet scrubber.

dioxin congener's ambient concentrations and depositions in every sector within the impact areas, which was $200 \times 200 \mathrm{~m}$. We modeled dioxin's dispersion in vapor and particle phases separately and incorporated their vapor-particle partition to obtain average air concentrations and depositions in each sector (Hunt and Maisel, 1992; USEPA, 1994a). Third, ISCST-modeled air-deposition rates were used to calculate the concentrations of each congener in the soil of each sector, considering firstorder transport and loss mechanisms of volatilization, erosion, surface runoff, leaching, and degradation (USEPA, 1993, 1994b). Fourth, the concentrations of each congener in water bodies were calculated by considering loadings and loss mechanisms. The loadings into a water body included dry and wet deposition, diffusion, surface runoff, and erosion from the associated watershed. The first-order loss mechanisms included volatilization, sediment burial, and degradation (USEPA, 1993, 1994b). Fifth, the concentrations of each congener in aboveground produce, root vegetables, fruits, fish, beef, dairy, pork, chicken, and eggs in each sector were estimated through food chain modeling (USEPA, 1992, 1994b). Sixth, we overlaid the grid-divided sectors with the smallest administrative units (SAUs) by using a geological information system (GIS) to determine the each congener's concentrations in air, terrestrial, and aquatic foods of individual SAUs. The superimposition of SAUs onto the Cartesian grid was necessary because SAU was the smallest geographic area for food production data in Taiwan. Lastly, we used the information on contact rates between receptors and exposure media to determine resident's dioxin exposure through inhalation and ingestion of various foods in each SAU of the nine incinerators. The following equation calculated the average daily intake of dioxins $\mathrm{ADI}_{i m}^{(m)}$ (mg TEQ per kilogram per day) from exposure medium $i$ (air, beef, pork, etc.) in the impact area of incinerator $m$, when all food consumption was assumed to be supplied locally.

$$
\begin{aligned}
\mathrm{ADI}_{i m}^{(m)} & =\sum_{k}\left(\mathrm{ADI}_{i k m}^{(m)} \times \mathrm{TEF}_{k}\right) \\
& =\sum_{k}\left(C_{i k}^{(m)} \times \mathrm{TEF}_{k}\right) \times \frac{\mathrm{IU}_{i}}{\mathrm{BW}} \times \frac{\mathrm{EF} \times \mathrm{ED}}{\mathrm{AT}}
\end{aligned}
$$

where $\mathrm{TEF}_{k}$ is the international toxicity equivalency factor of congener $k$ based on its relative toxicity to 2,3,7,8-TCDD. $C_{i k}^{(m)}$ kilogram for foods) is the concentration of congener $k$ in exposure medium $i$ produced in the impact area of incinerator $m . \mathrm{IU}_{i}$ (cubic meters per 
day for inhalation and kilograms per day for ingestion) is the contact rate of exposure medium $i$ (inhalation rates of air, ingestion rates of various foods). EF (days per year) is the exposure frequency, ED (year) is the exposure duration, and AT (day) is the averaging time (i.e., lifetime for cancer risk estimation). BW ( $\mathrm{kg}$ ) is the body weight of receptors.

We used site-specific environmental and exposure parameters in our calculations. In particular, we randomly selected 600 adults to measure their inhalation rates and used body weight and the ingestion rates of various food items from results of the Nutrition and Health Survey in Taiwan (Taiwan Department of Health, 1998). The Survey compiled detailed statistics of the nutritional and health conditions, lifestyles, and activity patterns of 10,080 randomly selected Taiwan citizens during 19931996. The consumption rates of root vegetables and aboveground vegetables were obtained from the Taiwan Agricultural Yearbook (Taiwan Department of Agriculture, 1999a).

\subsection{Risk characterization}

The individual cancer risk for the residents living in the SAU with the largest air deposition for each incinerator is used as the risk descriptor of this study. This was an upper-bound estimation approach that did not incorporate parameter uncertainty and spatial variation in dioxin deposition. The linear and nonthreshold doseresponse model with the cancer slope factor (CSF), $1.56 \times 10^{5}\left(\mathrm{mg} \mathrm{TEQ}^{-1} \mathrm{~kg}\right.$ day), was used (CrawfordBrown, 1997; USEPA, 1999). The cancer risk for residents living around incinerator $m$ as a result of contact with exposure medium $i$ produced in the area of incinerator $m$, was calculated as follows:

$R_{i m}^{(m)}=\left[1-\exp \left(\mathrm{ADI}_{i m}^{(m)} \times \mathrm{CSF}\right)\right] \approx \mathrm{ADI}_{i m}^{(m)} \times \mathrm{CSF}$

\subsection{Risk transfers}

Risk transfers among nine incinerator-impacted areas were assessed under two exposure scenarios of sufficient food production (SFP) and insufficient food production (IFP). For the former scenario, we assumed that all residents living around an incinerator consumed locally contaminated foods only. In other words, we assumed food production in incinerator-impacted areas could meet all residents' consumption needs. Under such an exposure scenario, we can assess nine incinerators' site-specific risks without risk transfers by the above equations (1) and (2). For the later scenario, the actual data of food sale and distribution were used to calculate production consumption ratio between two incinerators, $\mathrm{PCR}_{i n}^{(m)}$, which is defined as the contribution of supply of food item $i$ from the area around incinerator $n$ to the food consumption in the vicinity of incinerator $m$. The transfer of dioxin risks from incinerator $n$ to the area around incinerator $m$ as a result of the transportation of food item $i$ was then the multiplication of $R_{i n}^{(n)}$ and $\mathrm{PCR}_{i n}^{(m)}$. Note that there was no risk transfer between incinerators for air inhalation and soil ingestion since the two pathways only impacted local study areas. The total risks received by residents around incinerator $m$ as a result of contact with food item $i, R_{i}^{(m)}$, was then the summation of risk transfers from all of the nine incinerators.

$R_{i}^{(m)}=\sum_{n} R_{i n}^{(n)} \times \mathrm{PCR}_{i n}^{(m)}$

In order to obtain PCRs for this study, the Taiwan Area agricultural Products Wholesale Market Yearbook (Taiwan Department of Agriculture, 1999b), which contained information on the sources and distribution of all food items in all wholesale markets each year in Taiwan, was used to identify the supply-consumption network of various foods between all the cities and counties of Taiwan. By combining the food supply and consumption data among counties where these nine incinerators were situated and the data of production ratios between impacted areas and the counties, we can estimate PCRs for all food items consumed in the nine incineratorimpacted areas.

\section{Results}

\subsection{Food production consumption ratio}

Table 2 summarizes PCRs of seven food items from the perspective of receiving incinerators. The proportion of locally produced food within individual impact areas ranged from $0 \%$ to $26.4 \%$ for nine incinerators. Each impact areas' received food supplies from the other eight impact areas were from $0 \%$ to $10.4 \%$. Apparently, $72.9-100 \%$ of food consumed in the incinerator impact areas were from the areas without incinerators. The concentrations of dioxins in the foods from the areas without incinerator impact were assumed zero in our calculation.

\subsection{Comparisons of risk under SFP and IFP scenarios}

Fig. 2 shows the estimated risks from 10 exposure pathways for the nine incinerators under SFP and IFP scenarios. The cancer risks for individual incinerators ranged from $1.4 \mathrm{E}-8$ (Incinerator $\mathrm{F}$ ) to $7.1 \mathrm{E}-5$ (Incinerator A) in the SFP scenario. The five older incinerators (A, $\mathrm{B}, \mathrm{E}, \mathrm{H}$, and I) all had risk values greater than one in a million. Ingestion of eight food items was the main route of dioxin exposures, which accounted for more than $98 \%$ risk values. Egg and chicken were two major dioxin sources, which accounted for $14-35 \%$ and $11-26 \%$ of total ingestion risks, respectively. 
Table 2

Production consumption ratios (\%) of seven food items for nine incinerators

\begin{tabular}{|c|c|c|c|c|c|c|c|c|c|c|c|c|c|c|c|c|c|c|c|c|c|}
\hline \multirow{2}{*}{$\frac{\text { Food item }}{\text { Importer }}$} & \multicolumn{3}{|c|}{ Vegetable } & \multicolumn{3}{|l|}{ Fruit } & \multicolumn{3}{|l|}{ Pork } & \multicolumn{3}{|l|}{ Egg } & \multicolumn{3}{|l|}{ Milk } & \multicolumn{3}{|c|}{ Chicken } & \multicolumn{3}{|l|}{ Fish } \\
\hline & Local & All others & Sum & Local & All others & Sum & Local & All others & $\overline{\text { Sum }}$ & Local & All others & $\overline{\text { Sum }}$ & Local & All others & Sum & Local & All others & $\overline{\text { Sum }}$ & Local & All others & Sum \\
\hline \multicolumn{22}{|l|}{ Receiver } \\
\hline A & 0.5 & $0-7.4$ & 14.2 & 0.2 & $0-4.6$ & 7.0 & 0 & $0-1.1$ & 3.1 & 0 & 0 & 0 & 0 & $0-4.2$ & 6.6 & 0.2 & $0-10.4$ & 13.1 & 0 & $0-2.0$ & 3.0 \\
\hline B & 1.4 & $0-7.4$ & 15.1 & 0.8 & $0-4.6$ & 7.6 & 0 & $0-1.1$ & 3.1 & 0 & 0 & 0 & 0 & $0-4.2$ & 6.6 & 0.3 & $0-10.4$ & 13.2 & 0 & $0-2.0$ & 3.0 \\
\hline $\mathrm{C}$ & 1.9 & $0-7.4$ & 15.6 & 0.3 & $0-4.6$ & 7.1 & 0 & $0-1.1$ & 3.1 & 0 & 0 & 0 & 0 & $0-4.2$ & 6.6 & 0.2 & $0-10.4$ & 13.1 & 0 & $0-2.0$ & 3.0 \\
\hline D & 0.8 & $0-6.8$ & 11.8 & 1.3 & $0-3.7$ & 5.7 & 1.4 & $0-0.2$ & 1.8 & 7.4 & 0 & 7.4 & 0.4 & $0-2.3$ & 4.0 & 3.5 & $0-1.3$ & 5.5 & 10.6 & 0 & 10.6 \\
\hline E & 3.0 & $0-1.2$ & 5.2 & 0.2 & $0-2.1$ & 3.7 & 2.7 & $0-0.6$ & 4.4 & 4.4 & 0 & 4.4 & 2.2 & $0-3.3$ & 7.4 & 26.4 & $0-0.3$ & 27.1 & 2.6 & $0-2.4$ & 6.0 \\
\hline F & 0.8 & $0-1.8$ & 3.1 & 11.4 & $0-0.4$ & 12.4 & 4.9 & $0-1.3$ & 6.2 & 10.9 & 0 & 10.9 & 25.3 & $0-1.0$ & 26.3 & 0.7 & $0-4.5$ & 9.9 & 0.2 & $0-4.1$ & 7.9 \\
\hline G & 12.1 & $0-1.6$ & 15.1 & 0.1 & $0-2.5$ & 3.7 & 2.2 & $0-0.6$ & 3.4 & 8.8 & 0 & 8.8 & 9.9 & $0-0.7$ & 10.7 & 3.6 & $0-4.5$ & 9.9 & 5.1 & $0-0.4$ & 5.5 \\
\hline $\mathrm{H}$ & 0.1 & $0-0.8$ & 1.7 & 2.4 & $0-8.6$ & 13.5 & 0.8 & $0-0.8$ & 2.5 & 0 & 0 & 0 & 0 & $0-3.8$ & 5.9 & 0.1 & $0-10.4$ & 13.1 & 0.1 & $0-0.5$ & 1.1 \\
\hline I & 0.2 & $0-0.8$ & 1.8 & 2.9 & $0-8.6$ & 14.0 & 1.0 & $0-0.8$ & 2.7 & 0 & 0 & 0 & 0 & $0-3.8$ & 5.9 & 0.1 & $0-10.4$ & 13.1 & 0.1 & $0-0.5$ & 1.1 \\
\hline
\end{tabular}

Local: PCR from the local incinerator impact area.

All others: ranges of PCRs from the other eight incinerator impact areas. 


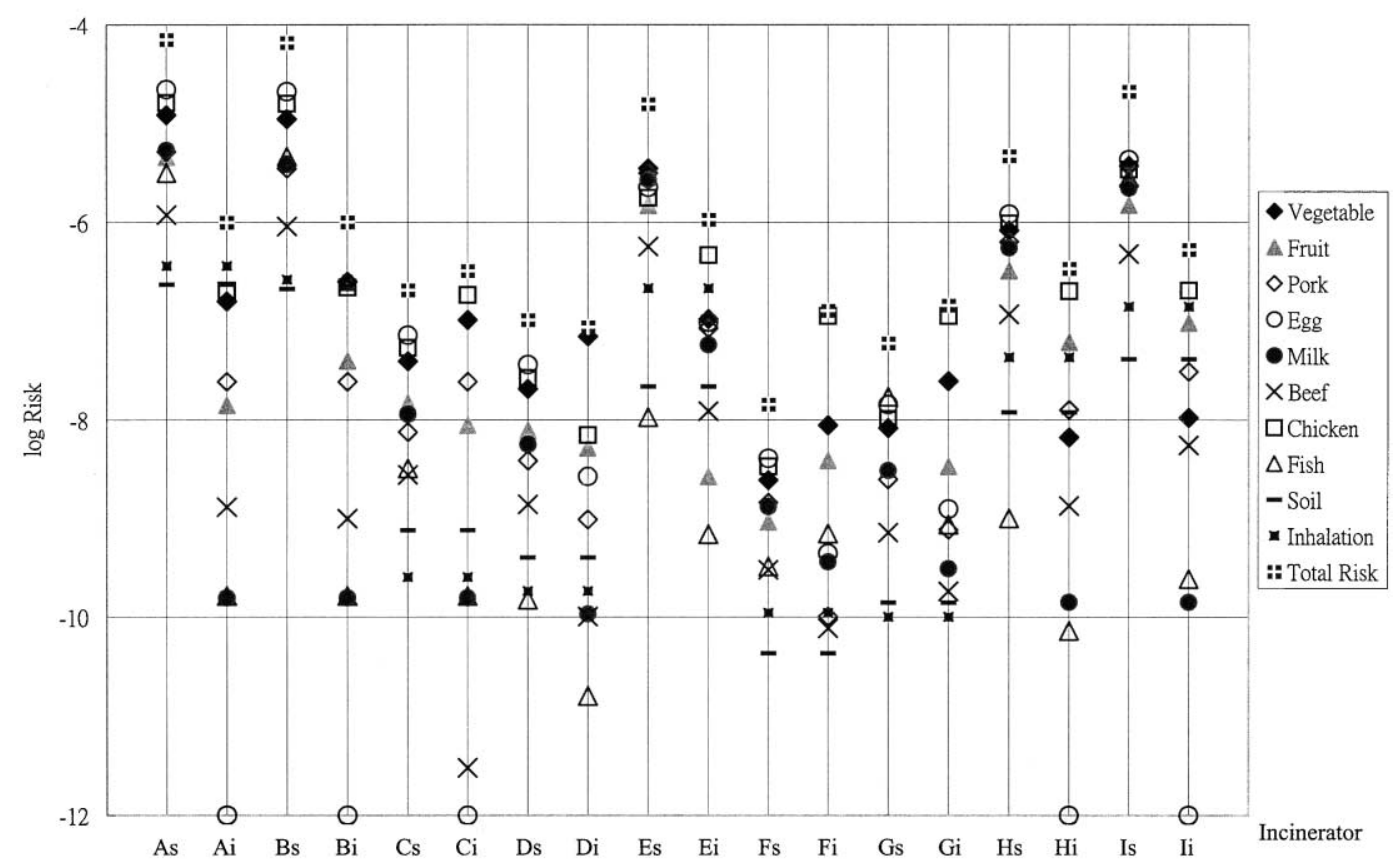

Fig. 2. The estimated risks from 10 exposure pathways for the nine incinerators under sufficient and insufficient food production scenarios.

The cancer risks for individual incinerators ranged from $8.7 \mathrm{E}-8$ (Incinerator D) to $1.1 \mathrm{E}-6$ (Incinerator $\mathrm{E}$ ) in ISP scenario. Three incinerators (A, B, E) had risk values slightly greater than $1 \mathrm{E}-6$. Compared to the SFP scenario, five older incinerators $\mathrm{A}, \mathrm{B}, \mathrm{E}, \mathrm{H}$, and I with higher dioxin emissions deceased their risk values, whereas three new incinerators $\mathrm{C}, \mathrm{F}$, and $\mathrm{G}$ with low dioxin emissions increased their risk values in the IFP scenario. We also found that the range of risk estimates among nine incinerators decreased from an order of 3 in the SEP scenario to an order of 1 in the IFP scenario. Although food ingestion with $64-99 \%$ of total risk remained the main route of dioxin exposure pathway in the IFP scenario, the food items accountable for risks were somewhat different from those in the SPF scenario. Chicken with $8-78 \%$ of total ingestion risks and vegetables with $0.2-81 \%$ of total ingestion risks were two major food items of dioxin exposure in the IPF scenario.

\subsection{Risk transfers between incinerators}

As shown in Fig. 3, risk transfers among nine incinerator impact areas were significant. We found that only the impact

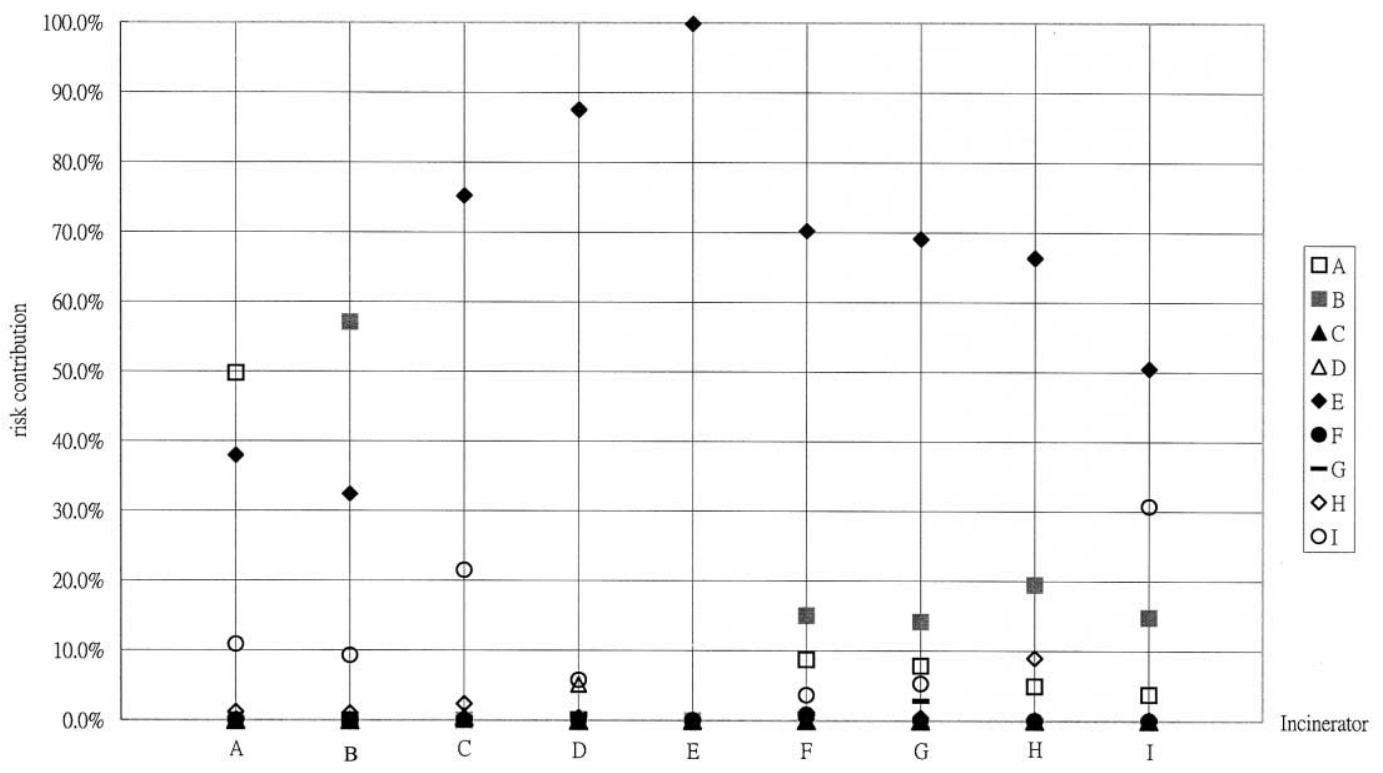

Fig. 3. The percentages of risk transfers across nine incinerator impact areas. 
Table 3

The percentage of ingestion risks from local producers and top two importers of vegetables, fruits, chicken, and pork for nine incinerators

\begin{tabular}{|c|c|c|c|c|c|c|c|c|c|c|c|c|}
\hline \multirow{2}{*}{$\frac{\text { Food item }}{\text { Importer }}$} & \multicolumn{3}{|c|}{ Vegetables } & \multicolumn{3}{|l|}{ Fruits } & \multicolumn{3}{|c|}{ Chicken } & \multicolumn{3}{|l|}{ Pork } \\
\hline & Local & Top & $\overline{\text { Second }}$ & $\overline{\text { Local }}$ & Top & Second & Local & Top & $\overline{\text { Second }}$ & Local & Top & Second \\
\hline \multicolumn{13}{|l|}{ Receiver } \\
\hline A & 35.7 & E (32.0) & I (29.7) & 37.2 & I (43.5) & E (10.5) & 9.7 & E (89.3) & I $(0.8)$ & 0 & I (59.3) & E (28.1) \\
\hline B & 59.2 & E (20.3) & I (18.8) & 77.8 & I (15.3) & E (3.7) & 15.6 & E (83.4) & I (59.3) & 0 & I $(0.7)$ & E (28.1) \\
\hline $\mathrm{C}$ & 0.7 & E (49.5) & I (45.8) & 0.4 & I (68.9) & E (16.6) & 0.1 & E (98.8) & I (0.9) & 0 & I (59.3) & E (28.1) \\
\hline D & 0.2 & E (91.5) & I (6.9) & 1.9 & E (91.2) & B $(2.8)$ & 13.0 & E (85.1) & G (1.8) & 5.5 & E (92.4) & I (1.4) \\
\hline E & 99.8 & $\mathrm{G}(0.1)$ & $\mathrm{D}(0.1)$ & 79.9 & I (13.1) & D (3.1) & 99.9 & $\mathrm{G}(0.1)$ & 0 & 99.9 & $\mathrm{D}(0.02)$ & $\mathrm{G}(0.02)$ \\
\hline F & 0.2 & E (76.1) & I (20.6) & 2.7 & E (89.8) & I (4.3) & 0.1 & $\mathrm{E}(70.1)$ & B (16.9) & 70.2 & $\mathrm{G}(29.8)$ & 0 \\
\hline $\mathrm{G}$ & 4.1 & E (74.0) & I (20.0) & 0.1 & E (49.2) & B (39.8) & 0.3 & $\mathrm{E}(70.1)$ & B (16.9) & 6.8 & E (87.9) & $\mathrm{D}(2.8)$ \\
\hline $\mathrm{H}$ & 4.4 & E (68.7) & B (18.6) & 12.6 & B (73.5) & A (12.4) & 0.1 & E (90.7) & $\mathrm{B}(5.7)$ & 38.4 & E (61.4) & $\mathrm{F}(0.1)$ \\
\hline I & 39.3 & E (43.6) & B (11.8) & 44.2 & B (47.0) & A (7.9) & 1.6 & E (89.4) & B (5.6) & 74.8 & $\mathrm{E}(25.1)$ & $\mathrm{F}(0.1)$ \\
\hline
\end{tabular}

Local: ingestion risk contributed by foods produced in the local incinerator impact area.

Top: The incinerator impact area with the biggest ingestion risk importation for respective receiving incinerator impact areas.

Second: The incinerator impact area with the second biggest ingestion risk importation for respective receiving incinerator impact areas.

areas of Incinerators A, B and E still received $50-99 \%$ of total ingestion risks from their locally produced food, respectively. For the other six incinerator impact areas, Incinerator $\mathrm{E}$ with $51-88 \%$ of total ingestion risks was the most important exporting source of dioxin risks. Incinerator $\mathrm{B}$ was the other exporting source of dioxin risks, which accounted for up to $22 \%$ of risk transfers.

To identify food items responsible for risk transfers, we further calculated risk transfers via PCRs of seven food items among nine incinerator impact areas. Example results of risk transfers via vegetables, fruits, chicken, and pork presented in percent risk contributions from local as well as two most important importing sources are summarized in Table 3. For these four food items, Incinerators E, I, and B were three major exporting sources of dioxins. For the risks of vegetable ingestion, Incinerator E accounted for $20.3-91.5 \%$ risks of eight other incinerator impact areas, Incinerator I accounted for 6.9$45.8 \%$ risks of five other incinerator impact areas, and Incinerator B accounted for $11.8-18.6 \%$ risks of two other incinerator impact areas. For the fruit ingestion pathway, Incinerator E accounted for 3.7-91.2\% risks of six other incinerator impact areas, Incinerator I accounted for $4.3-68.9 \%$ risks of five other incinerator impact areas, and Incinerator B accounted for $2.8-73.5 \%$ risks of four other incinerator impact areas. For chicken ingestion, all incinerator impact areas received risk predominantly from Incinerator $\mathrm{E}$, which accounted for $70.1-99.9 \%$ risks. For pork ingestion, Incinerators I and $\mathrm{E}$ were two major risk contributors for the other seven incinerator areas except Incinerator F, which accounted for $1.4-87.9 \%$ risks.

\section{Discussion}

We found significant risk transfers among nine incinerator impact areas even though the total amount of food transportation across these areas was no greater than $10.4 \%$ in this study. By considering risk transfers, we observed decreased risks in impact areas with high dioxin emissions but increased risks in areas with lower dioxin emissions. Accordingly, the nine incinerators' difference in dioxin risks was less than 10-fold although their difference in emissions was 10,000-fold. By considering cross-incinerator food transportation, vegetables replaced eggs as an important food item responsible for dioxin risks. Our findings had general implication of improving the risk assessment methodology. Our results indicated that realistic risk assessments on incinerator-related dioxins should always consider risk transfers among different food sources from various incinerators simultaneously. Better characterization of routes played as important role as emission measurements in performing risk assessments on dioxins from incinerators. The production consumption ratio between two incinerators, PCR, proposed in our study proved to be a useful descriptor to refine exposure assessments for situations when there were complex transportation and exchanges of food.

The fact that Incinerators $\mathrm{E}$ and I exported risks to other locations via vegetables, fruits, chicken, and pork had practical policy implication too. We should reconsider an incinerator's location while trying to lower its emissions in order to lower dioxin risks associated with incinerators in one specific site as well as in a greater area. Apparently, an agricultural area with important foodstuff where Incinerator E was situated was not an appropriate incinerator's location due to its high export of dioxin risks.

The limitations of this research should be addressed when we interpret the study results. First, the actual impact areas may be larger than the model-defined $8 \times 8-\mathrm{km}$ areas for individual incinerators. This is especially true for older incinerators $\mathrm{A}, \mathrm{B}$, and $\mathrm{E}$ with greater dioxin emissions. Second, the actual dioxin transfers can be more complicated than this paper presented because another 12 major municipal incinerators and 150 smaller incinerators currently without dioxin data were not assessed in our study. Third, spatial variation in dioxin deposition may affect risk transfers, which were not addressed by our current upper-bound 
estimation approach. Lastly, we were unable to estimate the uncertainty associated with the risk transfers because we used a parameter's average values only but not its variability in our models.

With all these limitations in mind, we still think our methods are basically scientifically sound and our findings are valid for making recommendations on future risk assessments on incinerators in Taiwan. We claim that risk assessments on incinerators are better based on the countrywide rather than site-specific scale in Taiwan because of large and complicated cross-incinerator risk transfers. We should place high priority on implementing control measures to lower dioxin emissions in important food-exporting areas like Incinerator E. In order to improve dioxin-related health risk assessment in the future, we recommend analyzing dioxin contents in eggs, chicken, and vegetables consumed by residents in the impact areas, as well as performing quantitative uncertainty analysis on key parameters in the multimedia transportation and exposure models.

\section{References}

Alcock RE, Gemmill R, Jones KC. Improvements to the UK PCDD/PCDF and $\mathrm{PCB}$ atmospheric emission inventory following an emission measurement programme. Chemosphere 1999;38:759-70.

California EPA. CalTOX: a multimedia total exposure model for hazardouswaste sites, Sacramento: The Office of Scientific Affairs, 1993.

Crawford-Brown DJ. Theoretical and mathematical foundations of human health risk analysis. Norwell, MA: Kluwer Academic Publishers, 1997.

Crawford-Brown DJ. Risk-based environmental decisions: methods and culture. Norwell, MA: Kluwer Academic Publishers, 1999.

Gotoh Y, Nakamura Y. Japanese source inventory focusing on the emission reduction measures in the manufacturing industries sector. Organohalogen 1999;41:477-80.

Hunt GT, Maisel BE. Atmospheric concentrations of PCDDs and PCDFs in southern California. J Air Waste Manage Assoc 1992;42:672-80.

Lauretis RD. Dioxins and furans Italian national and local emission inventories. Organohalogen 1999;41:487-9.

Levin A, Fratt DB, Leonard A, Bruins R, Fradkin L. Comparative analysis of health risk assessments for municipal waste combustors. J Air Waste Manage Assoc 1991;41:20-31.

McKone TE. Human exposure to chemicals from multiple media and through multiple pathways: research overview and comments. Risk Anal 1991a;11:5-10.

McKone TE. Estimating human exposure through multiple pathways from air, water, and soil. Regul Toxicol Pharmacol 1991b;13:36-61.

Päpke O. PCDD/PCDF: human background data for Germany, a 10-year experience. Environ Health Perspect 1998;106(Suppl 2):723-31.

Taiwan Department of Agriculture. Taiwan agricultural yearbook (in Chinese). Taipei, Taiwan, 1999a.

Taiwan Department of Agriculture. Taiwan area agricultural products wholesale market yearbook (in Chinese). Taipei, Taiwan, 1999b.

Taiwan Department of Health. Nutrition and health survey in Taiwan (in Chinese). Taiwan, 1998.

USEPA. MMSOIL: multimedia contaminant fate, transport, and exposure model. Washington, DC: Office of Research and Development, 1992.

USEPA. Addendum: methodology for assessing health risks associated with indirect exposure to combustor emissions. Washington, DC: Office of Solid Waste, 1993.

USEPA. Health assessment for 2,3,7,8-TCDD and related compounds. Public review draft, EPA/600/EP-92/001. Washington, DC: Office of Research and Development, 1994a.

USEPA. Guidance for performing screening level risk analyses at combustion facilities burning hazardous wastes. Washington, DC: Office of Emergency and Remedial Response, 1994b.

USEPA. Human health and ecological risk assessment support to the development of technical standards for emissions from combustion units burning hazardous wastes. Background document, EPA/68/w6/0053, 1999.

World Health Organization (WHO). Dioxins and their effects on human health. Fact sheet No.225, June 1999. 